\title{
Indigenous yeast communities in the environment of "Rovello bianco" grape variety and their use in commercial white wine fermentation
}

\author{
Nicola Francesca $\cdot$ Mario Chiurazzi . \\ Raffaele Romano • Maria Aponte · \\ Luca Settanni · Giancarlo Moschetti
}

Received: 6 July 2009/ Accepted: 9 September 2009

(C) Springer Science+Business Media B.V. 2009

\begin{abstract}
The indigenous yeast communities associated with several vineyard habitats were analysed. Wild yeasts were isolated, differentiated at strain level and identified. A phylogenetic tree based on partial 26S rRNA genes was constructed. The strains were characterized and the indigenous Saccharomyces cerevisiae GR1 was then used to carry out a vinification process and compared with a commercial yeast. Wines obtained were subjected to chemical and sensory analysis. The comparison between the two products highlighted differences due to the fermenting strains employed. The vineyard environment was found to strongly influence the composition of yeast communities, thus, confirming the theory of 'terroir' on the expression of wines. Moreover, vineyard inhabiting birds were in part responsible for the dissemination of fermentative yeasts during their feeding activities.
\end{abstract}

Keywords Birds - Grape variety "Rovello bianco" or "Greco muscio" · PCR-DGGE - Saccharomyces cerevisiae . Vineyard environment . Wild yeasts . Wine fermentation

N. Francesca $\cdot$ L. Settanni · G. Moschetti $(\bowtie)$

SENFIMIZO Department, Section of Phytopathology and Agricultural Microbiology, University of Palermo, Viale delle

Scienze 4, 90128 Palermo, Italy

e-mail: moschett@unipa.it; moschett@unina.it

M. Chiurazzi · R. Romano · M. Aponte

Department of Food Science, University of Naples Federico II,

Via Università 100, 80055 Portici, Napoli, Italy

\section{Introduction}

Many factors are known to affect the microbial ecology of wine production; the chemical composition of grape juice and the fermentation processes show a major impact (Fleet 2003). Fungi, yeasts, lactic and acetic acid bacteria maybe involved in different ways in winemaking. Yeasts are paramount in the biochemical interaction with the musts derived from the varieties of Vitis vinifera and other grape species (Pretorius 2000). Species of the genera Candida, Hanseniaspora, Pichia, Torulaspora, Hansenula, Issatchenkia, Metschnikowia, Kluyveromyces and Zygosaccharomyces generally grow during the first phases of fermentation, while the presence of Saccharomyces cerevisiae increases proportional to ethanol concentration (González et al. 2006; Lopandic et al. 2008).

The composition of yeast communities on grapes had been shown to be dependent on several factors, including the geographical location of the vineyard (Longo et al. 1991; Parrish and Carrol 1985), the type of soil (Farris et al. 1990), the age of the vineyard, the grape variety, the harvesting technique (Martini et al. 1980; Pretorius et al. 1999; Rosini et al. 1982), the degree of grape maturation (Rosini et al. 1982) and the grape sanity (Prakitchaiwattana et al. 2004). Furthermore, it has been demonstrated that certain yeast strains are fully adapted to a specific climatic environment and/or substrate (Esteve-Zarzoso et al. 2000). Some oenologists admit that good results can be obtained only with selected yeast starters originating from the micro-area where wines are produced. Most of the yeasts present during wine fermentation derive from the vineyard environment, but a deeper understanding of the factors influencing yeast diversity in vineyards is needed in order to assist 
wine-makers in the process of making decisions during vinification.

Winemakers may either use commercial dry yeasts (CDY) or let the musts to be spontaneously fermented. The last method is rather questionable, since wine quality relies on the resident yeast biota whose composition is subjected to yearly fluctuations. However, there might be pitfalls in production also when using CDY, for instance, one of the main issues is due to the wine taste evenness and the different wines are less distinguishable from one another. Recently, in an attempt to enhance distinctive aromatic characteristics, some research groups have focused on the selection of yeasts from restricted areas (Esteve-Zarzoso et al. 2000; Orlic et al. 2007). The inoculation of musts with S. cerevisiae strains selected from indigenous populations, at concentrations allowing the development of wild yeasts, can control the alcoholic fermentation better than CDY, as well as contribute to the production of more balanced wines (Fleet 1990; Martinez et al. 1989; Moreno et al. 1991).

The objectives of the present study, were: (1) monitoring the "indigenous" yeast communities of the different habitats related to the vineyard, such as grapes, leaves and cortex of grapevines, must, soil, grass, insects and birds, by means of traditional and molecular methods; (2) screening the different strains for their suitability for must fermentation; and (3) comparing a $S$. cerevisiae strain selected for the best technological performances to a commercial starter, by evaluating differences in the final wine produced.

\section{Materials and methods}

Sampling and yeast isolation

Grape, leave and cortex of grapevine, must, soil, grass, insect and bird samples (Table 1) from four vineyards (Coste, Fontana Iuto, Case d'alto and Corridore) producing the grape variety 'Greco Muscio' (also known as 'Rovello bianco'), located in Taurasi (Avellino, Campania region, Italy) between 300 and $377 \mathrm{~m}$ of height above sea level, were collected during the vintage 2002-2003. The above grape variety, although already cultivated for centuries in this region (Froio 1875), has been recently found to be distinct from the others cultivated within Avellino province (Francesca et al. 2009) by simple sequence repeats (SSRs) and ampelographic analyses. The sampling was made in three $100 \mathrm{~m}^{2}$-subareas (representing three replicates) of the same vineyard, distant approximately $100-500 \mathrm{~m}$ from each other.

Grapes were examined in different conditions: healthy, pecked at by birds and infected by Botrytis cinerea. Twenty bunches were harvested from several plants (5-10) within each sub-area and $500 \mathrm{~g}$ of berries were then randomly collected, crushed in sterile bags and blended in a stomacher (Laboratory Blender Stomacher 400, Seward Medical, London, UK) for $5 \mathrm{~min}$ at high speed.

Fifty grams of grass, leaves and barks were put in bags containing equal volume of Ringer's solution (SigmaAldrich, Milano, Italy) and blended as above.

Table 1 Yeasts populations associated with vineyard-related samples

\begin{tabular}{|c|c|c|c|}
\hline Samples & Counts $(\mathrm{CFU} / \mathrm{g})^{\mathrm{a}}$ & Isolates $^{c}$ & Yeast species (number of strains) \\
\hline Bark & $1.16 \times 10 \pm 5.01$ & 8 & H. uvarum (2), M. fructicola (1) \\
\hline Birds & - & 20 & H. uvarum (6), C. albicans (1) \\
\hline Botrytis affected grapes & $3.16 \times 10^{4} \pm 2.01 \times 10^{4}$ & 6 & H. uvarum (1), I. terricola $(1)$ \\
\hline Grapes pecked at by birds & $7.94 \times 10^{4} \pm 7.94 \times 10^{3}$ & 32 & $\begin{array}{l}\text { H. uvarum (3), I. terricola (2), Metschnikowia spp. (1), } \\
\text { M. fructicola (2), P. fermentans (1), S. cerevisiae (1) }\end{array}$ \\
\hline Grass & $1.99 \times 10 \pm 3.16$ & 6 & M. fructicola (1), Cry. flavescens (1) \\
\hline Healthy grapes & $6.31 \times 10^{3} \pm 1.99 \times 10^{3}$ & 14 & $\begin{array}{l}\text { C. stellata (1), Metschnikowia spp. (1), R. glutinis (1), } \\
\text { S. cerevisiae (1), H. uvarum (1), unknown (1) }\end{array}$ \\
\hline Insects & - & 10 & H. uvarum (1), Metschnikowia spp. (1), I. terricola (2) \\
\hline Leaves & $2.51 \times 10 \pm 3.16$ & 6 & H. uvarum (2), M. fructicola (1) \\
\hline Musts & $6.30 \times 10^{5} \pm 2.89 \times 10^{5 b}$ & 20 & $\begin{array}{l}\text { H. uvarum (2), Metschnikowia spp. (1), M. fructicola (1), } \\
\text { T. delbrueckii (1), Candida spp. (1) }\end{array}$ \\
\hline Soil & $1.25 \times 10 \pm 1.77$ & 2 & Unknown (1) \\
\hline
\end{tabular}


Five soil cores were collected for each subarea. Soil samples were carefully mixed, sieved through a $2 \mathrm{~mm}$ sieve, transferred in sterile bags and stored at $4^{\circ} \mathrm{C}$ (at longer for 3 days) before analyses were performed. Aliquots of $10 \mathrm{~g}$ were then suspended in $90 \mathrm{ml} 0.1 \%$ (w/v) sodium pyrophosphate and kept under agitation (180 rpm) on a rotary shaker for $30 \mathrm{~min}$ at room temperature.

Two kilograms of undifferentiated grapes coming from each vineyard were independently crushed to must in sterile plastic bags by using a stomacher and maintained at $4^{\circ} \mathrm{C}$ until analysis were performed, before fermentation took place.

Sample suspensions of grapes, grass, leaves, barks, soil and must were serially diluted in physiological $(0.9 \%$ $\mathrm{NaCl}$, w/v) solution and aliquots of $0.1 \mathrm{ml}$ were spread onto malt extract agar (Oxoid, Basingstoke, UK) added with chloramphenicol (100 $\mu \mathrm{g} / \mathrm{ml}$; MEAC).

Insects were sampled as follows: 100 individuals belonging to Drosophila spp. were trapped by the Scentry delta trap 1× (Great Lakes IPM, Inc., Vestaburg, MI), collected and squeezed one by one on a Petri dish with a drop of sterile saline solution. The resulting suspensions were streaked onto MEAC.

Birds were caught in two experimental sites, the first represented by the vineyard Fontana Iuto (Taurasi, AV) and the second was a dune situated on the Tirrenian coast closed the mouth of Volturno river (Caserta, Campania region, Italy) which represents an important stop-over for migrating birds (Scebba and Moschetti 1996). The day before grape harvest, a Mist-nets with four shelf-nets (100 m of length) was placed near the vine-rows to capture birds visiting grapes grown in Fontana Iuto site. Birds captured were treated with rings provided by the Istituto Nazionale Fauna Selvatica (INFS, Ozzano, Italy) and their mouths and cloacae were plugged with sterile cotton swabs and streaked onto MEAC plates. Birds' legs were also leaned directly on the plate surfaces. According to INFS procedures, birds were then released.

After incubation at $28^{\circ} \mathrm{C}$ for 3-4 days, a total of 124 yeast colonies were randomly chosen from all the samples analysed. At least two colonies per morphology were collected.

\section{DNA extraction and RAPD-PCR analysis}

In order to avoid clonal relatedness and to evaluate the overall yeast species diversity, the isolates were analysed by randomly amplified polymorphic DNA (RAPD)-PCR.

Cell lysis for DNA extraction was performed using the InstaGene Matrix kit (Bio-Rad Laboratories, Hercules, CA) following the manufacturer's instructions. RAPD-PCR was carried out in a total volume of $25 \mu \mathrm{l}$ containing ca. $20 \mathrm{ng}$ of template DNA, $3.5 \mathrm{mM} \mathrm{MgCl}_{2}, 0.4 \mathrm{mM}$ of each dNTP,
$0.6 \mu \mathrm{M}$ primer XD5 (5'-CTGGCGGCTG- $\left.3^{\prime}\right)$ or XD4 (5'-AGCAGCGTGG-3') (Moschetti et al. 1998), 2.5 U Taq polymerase (Invitrogen, La Jolla, USA) and $1 \times$ PCR buffer (Invitrogen). Amplifications were performed in a MyCycler thermocycler (Bio-Rad) using the following PCR program: initial template denaturation for $5 \mathrm{~min}$ at $94^{\circ} \mathrm{C}, 40$ cycles of denaturation for $1 \mathrm{~min}$ at $94^{\circ} \mathrm{C}$, annealing for $1 \mathrm{~min}$ at $31^{\circ} \mathrm{C}$ and extension for $2 \mathrm{~min}$ at $72^{\circ} \mathrm{C}$, with a final elongation for $7 \mathrm{~min}$ at $72^{\circ} \mathrm{C}$. PCR products were separated by electrophoresis on $1.5 \%(\mathrm{w} / \mathrm{v})$ agarose gel in $1 \times 40 \mathrm{mM}$ Tris-20 mM acetic acid-1 M EDTA (TAE) buffer. DNA fragments were visualized after staining with ethidium bromide $(0.5 \mu \mathrm{g} / \mathrm{ml})$ by a UV transilluminator and subjected to the pattern analysis software package Gel Compar Version 4.1 (Applied Maths, Kortrijk, Belgium). Calculation of similarities of band profiles was based on Pearson's product moment correlation coefficient. Dendrograms were obtained by means of the unweighted pair group method using arithmetic average clustering algorithm.

Partial 26S rRNA gene sequence analysis

The D1/D2 region of the 26S rRNA gene of strains showing the most diverse RAPD-PCR profiles were sequenced. DNA amplification was achieved with primers NL1 and NL4 (O'Donnell 1993). PCR reactions (50 $\mu 1$ final volume) contained ca. $10 \mathrm{ng}$ template DNA, $2.5 \mathrm{mM}$ $\mathrm{MgCl}_{2}, 0.25 \mathrm{mM}$ of each dNTP, $0.2 \mu \mathrm{M}$ of each primer, $2.5 \mathrm{U} \mathrm{Taq}$ polymerase (Invitrogen) and $1 \times$ PCR buffer (Invitrogen), were carried out in a MyCycler thermocycler. The following program was applied: $5 \mathrm{~min}$ at $95^{\circ} \mathrm{C}, 30$ cycles for $1 \mathrm{~min}$ at $95^{\circ} \mathrm{C}, 45 \mathrm{~s}$ at $55^{\circ} \mathrm{C}$ and $1 \mathrm{~min}$ at $72^{\circ} \mathrm{C}$ and a final extension for $7 \mathrm{~min}$ at $72^{\circ} \mathrm{C}$. PCR products were visualised as above-mentioned. The amplicons of $550 \mathrm{bp}$ were purified by the QIAquick PCR purification kit (Qiagen S.p.A., Milan, Italy) and sequenced using the primers employed for PCR amplification. DNA sequences were determined by the dideoxy chain termination method with the DNA sequencing kit (Perkin-Elmer Cetus, Emeryville, CA, USA) according to the manufacturer's instructions. All the sequences obtained were submitted to the GenBank/ EMBL/DDBJ under the accession numbers EU441884 to EU441914.

\section{Phylogenetic analysis}

Sequence alignment was performed with CLUSTALX (Thompson et al. 1997). Sequence and alignment manipulations were performed with GeneDoc program version 2.5.000 (Nicholas and Nicholas unpublished data). Positions available for analysis were $413 \mathrm{bp}$. Phylogenetic and molecular evolutionary analysis were conducted using 
MEGA version 3.1 (Kumar et al. 2004) with neighbourjoining as tree reconstruction method.

\section{Technological screening}

With the aim of selecting yeasts with potential in wine fermentation, all the strains were evaluated for their ability to grow onto modified ESY medium (Kish et al. 1983). The original composition of ESY includes glucose $(20 \mathrm{~g} / \mathrm{l})$, peptone $(5 \mathrm{~g} / \mathrm{l})$, yeast extract $(5 \mathrm{~g} / \mathrm{l})$, ethanol $(12 \% \mathrm{v} / \mathrm{v})$ and potassium metabisulphite (MBSK; $0.015 \% \mathrm{w} / \mathrm{v})$; in this work it has been adjusted for ethanol and MBSK concentration $(10 \% \mathrm{v} / \mathrm{v}$ and $0.02 \% \mathrm{w} / \mathrm{v}$, respectively), namely defined "modified ethanol sulphite agar" (MESA) medium. Ethanol concentration was lowered in order to allow a higher growth of injured Saccharomyces strains, while MBSK percentage was increased to be more restrictive for non-Saccharomyces strains.

The strains capable to grow on MESA were submitted to the hydrogen sulphide production test and laboratory-scale fermentation. Production of hydrogen sulphide was estimated by the blackening of the yeast culture on BiGGY (Bismuth Sulfite Glucose Glycerin Yeast Extract) agar (Oxoid) after 3 days of culture as described by Mortimer et al. (1994). A five-level scale was used for colour evaluation $(1=$ white, $2=$ light brown, $3=$ brown, $4=$ dark brown, $5=$ black). The estimation was carried out in duplicate.

In order to evaluate strain abilities to conclude a wine fermentation, tests were performed using concentrated must purchased from a local vineyard. The must was diluted 1:3 with sterile water and added with yeast extract $(2.5 \mathrm{~g} / \mathrm{l})$, it showed a final sugar content of about $24^{\circ} \mathrm{Brix}$ and $\mathrm{pH} 3.4$. Broth cultures in the stationary phase $(2 \mathrm{ml}$ each) were inoculated in $200 \mathrm{ml}$ of diluted must contained into $500 \mathrm{ml}$-volume flasks with and without addition of MBSK $(0.02 \% \mathrm{w} / \mathrm{v})$. Incubation was at 18 and $10^{\circ} \mathrm{C}$ for
12 days, thus four different conditions $\left(10\right.$ and $18^{\circ} \mathrm{C}$, with and without MBSK) were tested. Musts with two commercial dried yeasts were used as control and monitored for weight loss during fermentation. Analysis were carried out in duplicate.

\section{Factory-scale vinification process}

Saccharomyces cerevisiae GR1, showing the best technological performances, was employed for the fermentation of must from "Greco muscio" grapes of the vintage 2004. The winemaking process was carried out at the winery "Azienda Agricola Contrade di Taurasi di Enza Lonardo" located in Taurasi. The CDY Premium ${ }^{\circledR}$ Blanc $12 \mathrm{~V} \mathrm{~S}$. cerevisiae (Enologica VASON, Verona, Italy) was used in a control vinification. MBSK (120 mg/l) and polyvinylpolypyrrolidone (PVPP, $200 \mathrm{mg} / \mathrm{l}$ ) were added to the must, $24 \mathrm{~h}$ prior yeast inoculation. The scale-up of yeast inoculation started from the active dry yeast and the stored malt agar slant for CDY and strain GR1, respectively, grown in sterile must. The must was divided in two aliquots of 3001 each, put in 1,000 1-volume steel tanks, inoculated at about $10^{7}$ cells $/ \mathrm{ml}$, as evaluated by microscopic inspection (Thoma counting cell chamber). Fermentations were at $20^{\circ} \mathrm{C}$ for approximately 11 days following the local winemaking procedures. Wines were then transferred into 225 l-volume barriques (new purchased from the same retail company) and kept 3 months at a cellar temperature of $12^{\circ} \mathrm{C}$ before bottling. Microbiological sampling was aseptically performed with sterile plastic pipettes during the different phases of fermentation (Table 2). Analysis were carried out in duplicate.

Monitoring of yeast populations during fermentations

Yeast populations were monitored by a polyphasic approach using both culture-dependent and -independent

Table 2 Scheme of sampling during the large-scale vinification process

\begin{tabular}{|c|c|c|c|c|c|c|c|c|c|c|c|c|c|}
\hline \multirow{3}{*}{$\begin{array}{l}\text { Monitored } \\
\text { by }\end{array}$} & \multicolumn{13}{|l|}{ Samples } \\
\hline & \multicolumn{3}{|l|}{ Musts } & \multicolumn{3}{|c|}{ Tumultuous fermentation } & \multicolumn{6}{|c|}{ Barrique } & \multirow{2}{*}{$\begin{array}{l}\text { Bottled } \\
\text { wine } \\
(\mathrm{BW})\end{array}$} \\
\hline & $\begin{array}{l}\text { Just } \\
\text { pressed } \\
\text { (M1) }\end{array}$ & $\begin{array}{l}\text { Clarified } \\
\text { (M2) }\end{array}$ & $\begin{array}{l}\text { Inoculated } \\
\text { (M3) }\end{array}$ & $\begin{array}{l}4 \text { days } \\
\text { (F1) }\end{array}$ & $\begin{array}{l}8 \text { days } \\
(\mathrm{F} 2)\end{array}$ & $\begin{array}{l}11 \text { days } \\
\text { (F3) }\end{array}$ & $\begin{array}{l}7 \text { days } \\
\text { (B1) }\end{array}$ & $\begin{array}{l}15 \text { days } \\
\text { (B2) }\end{array}$ & $\begin{array}{l}22 \text { days } \\
\text { (B3) }\end{array}$ & $\begin{array}{l}33 \text { days } \\
\text { (B4) }\end{array}$ & $\begin{array}{l}51 \text { days } \\
\text { (B5) }\end{array}$ & $\begin{array}{l}90 \text { days } \\
\text { (B6) }\end{array}$ & \\
\hline Plating & $*$ & $*$ & $*$ & $*$ & $*$ & $*$ & $*$ & $*$ & $*$ & $*$ & $*$ & $*$ & $\mathrm{nc}$ \\
\hline $\begin{array}{c}\text { Molecular } \\
\text { analysis }\end{array}$ & $*$ & $*$ & $*$ & $*$ & $*$ & $*$ & $*$ & $\mathrm{nc}$ & $\mathrm{nc}$ & $\mathrm{nc}$ & $*$ & $\mathrm{nc}$ & $\mathrm{nc}$ \\
\hline $\begin{array}{r}\text { Chemical } \\
\text { analysis }\end{array}$ & $*$ & $\mathrm{nc}$ & nc & $*$ & $*$ & $*$ & $\mathrm{nc}$ & $\mathrm{nc}$ & $\mathrm{nc}$ & $\mathrm{nc}$ & $*$ & $\mathrm{nc}$ & $*$ \\
\hline
\end{tabular}

$n c$ not collected 
methods. Cultural strategy consisted of growth on MEAC and MESA. Yeast isolation and characterization by RAPD analysis was performed as above described.

PCR-DGGE represented the culture-independent tool used to reveal yeast species from total DNA of must and wine samples. DNA extractions were performed as described by Cocolin et al. (2001) and their amounts were standardized through gel electrophoresis to obtain ca. 10 ng of DNA template in each PCR mixture. Fungal 26/ 28S rRNA genes were amplified with two primer pairs: NL1/LS2 and 403-f/662-r (Sigler and Turco 2002). Primers NL1 and LS2 were used following the conditions reported by Cocolin et al. (2000). A touchdown PCR was performed with the primer set $403-\mathrm{f} / 662-\mathrm{r}: 5 \mathrm{~min}$ at $94^{\circ} \mathrm{C}, 10$ cycles for $30 \mathrm{~s}$ at $94^{\circ} \mathrm{C}, 1 \mathrm{~min}$ at $60-50^{\circ} \mathrm{C}$ (decrease of $1^{\circ} \mathrm{C}$ per cycle), and $2 \mathrm{~min}$ at $72^{\circ} \mathrm{C}$; followed by 20 additional cycles for $30 \mathrm{~s}$ at $94^{\circ} \mathrm{C}, 1 \mathrm{~min}$ at $50^{\circ} \mathrm{C}$ and $2 \mathrm{~min}$ at $72^{\circ} \mathrm{C}$. Final elongation was for $7 \mathrm{~min}$ at $72^{\circ} \mathrm{C}$. Each $50 \mu \mathrm{l}$ mixture contained $1 \times$ PCR Buffer (Invitrogen), $1.25 \mathrm{mM} \mathrm{MgCl}_{2}$, $250 \mu \mathrm{M}$ of each dNTP, $0.2 \mu \mathrm{mol}$ each primer, and $5 \mathrm{U}$ of Taq polymerase (Invitrogen).

The DGGE analysis was performed using a DCode Universal Mutation Detection System (Bio-Rad). Acrylamide gels $(8 \% \mathrm{w} / \mathrm{v})$ contained a denaturing gradient ranging from 40 to $60 \%$ of urea and formamide (a $100 \%$ denaturant solution consisted of $7 \mathrm{M}$ urea and $40 \% \mathrm{v} / \mathrm{v}$ deionized formamide), increasing in the direction of electrophoresis. DGGE was conducted in $1 \times$ TAE buffer at $200 \mathrm{~V}$ for $4 \mathrm{~h}$ at $60^{\circ} \mathrm{C}$. After runs, gel were stained in ethidium bromide solution and visualized on a UV transilluminator. DNA patterns were photographed using the Gel Doc 2000 documentation system (Bio-Rad). The amplicons were excised from gels and eluted overnight at $4^{\circ} \mathrm{C}$ in sterile water. Aliquots of $1-5 \mu$ l of DNA solution were used to re-amplify gene fragments. After fragment purity check on DGGE, PCR products were purified by the QIAquick PCR purification kit (Qiagen). DNA sequencing was performed as above-mentioned and the nucleotide sequences were submitted to the GenBank/EMBL/DDBJ under the accession numbers EU441915 to EU441921.

\section{Chemical analyses}

Must and wine samples were subjected to several chemical determination.

\section{Analysis of conventional parameters}

Measurements of $\mathrm{pH}$, total titratable acidity (TTA) and reducing sugars were performed following the methods of O.I.V. (1990). Volatile acidity was determined by the O.I.V. method modified by Huerta Diaz-Reganon (1996) for the determination of the end point. Total dry extract was evaluated following the procedure AOAC (1984). Acetaldehyde was determined by means of an enzymatic kit (Boehringer-Mannheim GmbH, Mannheim, Germany). Free and combined $\mathrm{SO}_{2}$ were measured with the O.I.V. method, while the end point was revealed by potentiometry as reported by Huerta Diaz-Reganon (1996). Soluble solid content was determined by classical methods. Alcoholic titre was evaluated after distillation with steam flow following the O.I.V. method. Turbidity was measured using a turbidimeter (2100 Hach, Loveland, CO) and the absorbance was determined at a wavelength of $420 \mathrm{~nm}$ in a $10 \mathrm{~mm}$ cell by UV-VIS Spectrophotometer (mod. 1601, Shimadzu, Tokyo, Japan).

\section{Total phenolic content}

Total phenols and polyphenols were quantified employing the Folin-Ciocalteu's reagent, using gallic acid as standard. The reaction mixtures contained $1 \mathrm{ml}$ of must or wine sample (adequately diluted), $250 \mu \mathrm{l}$ of carbonate-tartrate solution $\left(200 \mathrm{~g} / \mathrm{l} \quad \mathrm{Na}_{2} \mathrm{CO}_{3}, 12 \mathrm{~g} / \mathrm{l} \quad \mathrm{Na}_{2} \mathrm{C}_{4} \mathrm{H}_{4} \mathrm{O}_{6} \cdot 2 \mathrm{H}_{2} \mathrm{O}\right.$ in water) and $25 \mu \mathrm{l}$ of Folin-Ciocalteu's reagent. After 30 min reaction, the absorbance was measured at $700 \mathrm{~nm}$ wavelength. The results were expressed as $\mathrm{mg}$ of gallic acid equivalents (GAE)/l.

\section{Analysis of volatile organic compounds}

The volatile compounds were extracted from samples by means of the purge and trap concentrator/dynamic headspace system (Tekmar LSC 2000), equipped with Tenax trap (60/80 mesh, $100 \mathrm{mg})$. Wine samples $(20 \mathrm{ml})$ were preheated at $35^{\circ} \mathrm{C}$ for $5 \mathrm{~min}$ in a $25 \mathrm{ml}$ frit-less Spurger connected to the purge and trap unit. The carrier gas was helium flowing at a rate of $40 \mathrm{ml} / \mathrm{min}$ through the sample. Purge was for $15 \mathrm{~min}$ and desorption was carried out for $10 \mathrm{~min}$ at $180^{\circ} \mathrm{C}$. Transfer line temperature was $180^{\circ} \mathrm{C}$. Separation of volatile organic compounds (VOC) was performed on a Supelcowax 10 capillary column (60 $\mathrm{m} \times 0.25 \mathrm{~mm}$ id $0.25 \mu \mathrm{m}$ film thickness) using an Agilent Technologies 6890N gas chromatograph equipped with mass selective detector Agilent Technologies 5973N (GC-MSD system). The carrier gas was helium flowing at $1 \mathrm{ml} / \mathrm{min}$ (30 psi). The oven temperature was held for $8 \mathrm{~min}$ at $35^{\circ} \mathrm{C}$, then increased $3^{\circ} \mathrm{C}$ for min until $200^{\circ} \mathrm{C}$ and kept for $15 \mathrm{~min}$. The ion source temperature detector was $200^{\circ} \mathrm{C}$ and the injector temperature $180^{\circ} \mathrm{C}$, split (50:1). All mass spectra were recorded at ionizing energy of $70 \mathrm{eV}$, and scan range of 34-250 amu at a rate of $2.6 \mathrm{scan} / \mathrm{s}$. Identification was carried out by comparison of the GC retention times and mass spectrum with those of the reference compounds. All chromatographic peaks were also identified by comparing the mass spectra with those of the 
NIST/EPA/MSDC Mass Spectral database, with a similar index (SI) $>90 \%$. Quantification was carried out by the external standard method using calibration graphs of the corresponding volatiles and using the software Statgraphics Plus V.2 (STSC Inc., Rockville, MD).

All chemical analyses were carried out in triplicate and data were statistically elaborated by one-way analysis of variance (ANOVA) using STATISTICA program version 7.1 (StatSoft Italia srl, Vigonza, Italy). Statistical significance was attributed to $P \leq 0.05$.

\section{Sensory analysis}

A panel of 17 experienced wine tasters (chosen among oenologists and sommeliers) were asked to evaluate the sensory parameters of the two wines obtained from CDY and GR1 wine-making processes. The wines were served randomly in an odour free room at $21^{\circ} \mathrm{C}$ and the judges were isolated. Perceived intensities of 20 flavour attributes, including aroma, taste and mouth-feel attributes were scored from 1 to 10 , where 1 was considered "low" and 10 was "high". The following attributes were taken into account: intensity of smell, persistence, flowers, fresh fruits, mature fruits, citrus fruits, dry fruits, aromatic herbs, vanilla/pepper flavour, smoked/roasted, intensity of taste, persistence of taste, hot (alcohol), body, acidity, bitterness, saltiness, balance, 'Terroir' expression, overall evaluation. The panellists were previously trained to identify and score those 20 attributes. The resulting scores were averaged and compared. ANOVA test (StatSoft) was applied to find significant differences between the wines' attributes.

\section{Results}

Strain isolation, typing, identification and phylogenetic relationships

Grape samples with the largest yeast populations, in terms of cell concentration, were those damaged by $B$. cinerea or pecked at by birds, whereas the healthy grapes hosted less yeasts (Table 1). Leave, grapevine bark, grass and soil samples exhibited high numbers of mould colonies (results not shown), which probably limited yeast detection and isolation. A total of 124 yeast isolates were subjected to the typing analyses by RAPD-PCR, that recognised 44 strains. Yeast community composition was highly variable with regards to the vineyard location (results not shown), as well as the isolation source (Table 1).

Yeast biodiversity was high, since the vineyard related sources of isolation were found to harbour at least 10 species (two strains remained unspeciated) belonging to nine known genera. Hanseniaspora uvarum was the main species found, representing $43 \%$ of strains (Table 1). Metschnikowia spp. were also greatly represented in the vineyards. Strains belonging to the genera Candida, Pichia, Saccharomyces, Torulaspora and the species Cryptococcus flavescens were the most rarely isolated. Species diversity was more complex in the vineyards Coste and Fontana Iuto (results not shown). Regarding the source of isolation, healthy grapes and berries pecked at by birds were shown to harbour the most diverse yeasts communities, where $H$. uvarum dominated. Except soil and grass, it was detected in all the samples. Only two strains could be identified as $S$. cerevisiae. Due to the poor quality of the nucleotide sequences, strains from soil samples could not be identified.

Interestingly enough, some technological important yeasts (eight isolates able to grow on MESA medium) had a bird origin. In the first ringing site (vineyard of Taurasi), 14 birds were captured: four Black Caps (Sylvia atricapilla), four Robins (Erithacus rubecula), two Black birds (Turdus merula), two Blue Tits (Parus coeruleus) and two Long-tailed Tits (Aegithalus caudatus). Black birds carried most of the yeasts, whereas none of Long tits and Blue tits showed yeast presence. In the second ringing site (dune at Volturno mouth, a stop over site for migrating birds) a total of 16 birds were captured and checked for yeast presence: six Skylarks (Alauda arvensis), seven Black Caps, one Starling (Sturnus vulgaris), one Robin, one Stonechat (Saxicola torquata); no yeast was isolated.

Primers XD5 and XD4 showed a different discrimination ability, as calculated by using the discrimination index of Hunter and Gaston (1988) with the modification of Moschetti et al. (1998). The strains showing the most diverse combined RAPD-PCR profiles $(n=28)$ were used to construct a phylogenetic tree (Fig. 1) based on partial 26S rRNA genes. Strains with similar RAPD profiles had closely related DNA sequences. Each yeast species formed a distinct branch of the phylogenetic tree. High distances were observed for $C$. stellata and C. albicans strains.

\section{Technological screening}

Strains able to grow onto MESA plates are resistant to ethanol, thus, they may drive the late stages of fermentation. A total of seven strains of bird origin, isolated both from mouth and cloacae, overcame the technological screening onto MESA. None of the strains positive for growth on MESA plates was isolated from the insects.

All the yeasts selected from the first technological screening were then subjected to the hydrogen sulphide production test and, subsequently, to a laboratory-scale must fermentation. On the basis of must weight loss (Fig. 2), S. cerevisiae GR1 (low sulphite producer), 
Fig. 1 Phylogenetic relationships of representative strains of yeasts isolated from vineyard related samples based on 26S rRNA gene sequences. The bar indicates the number of nucleotide substitution per site

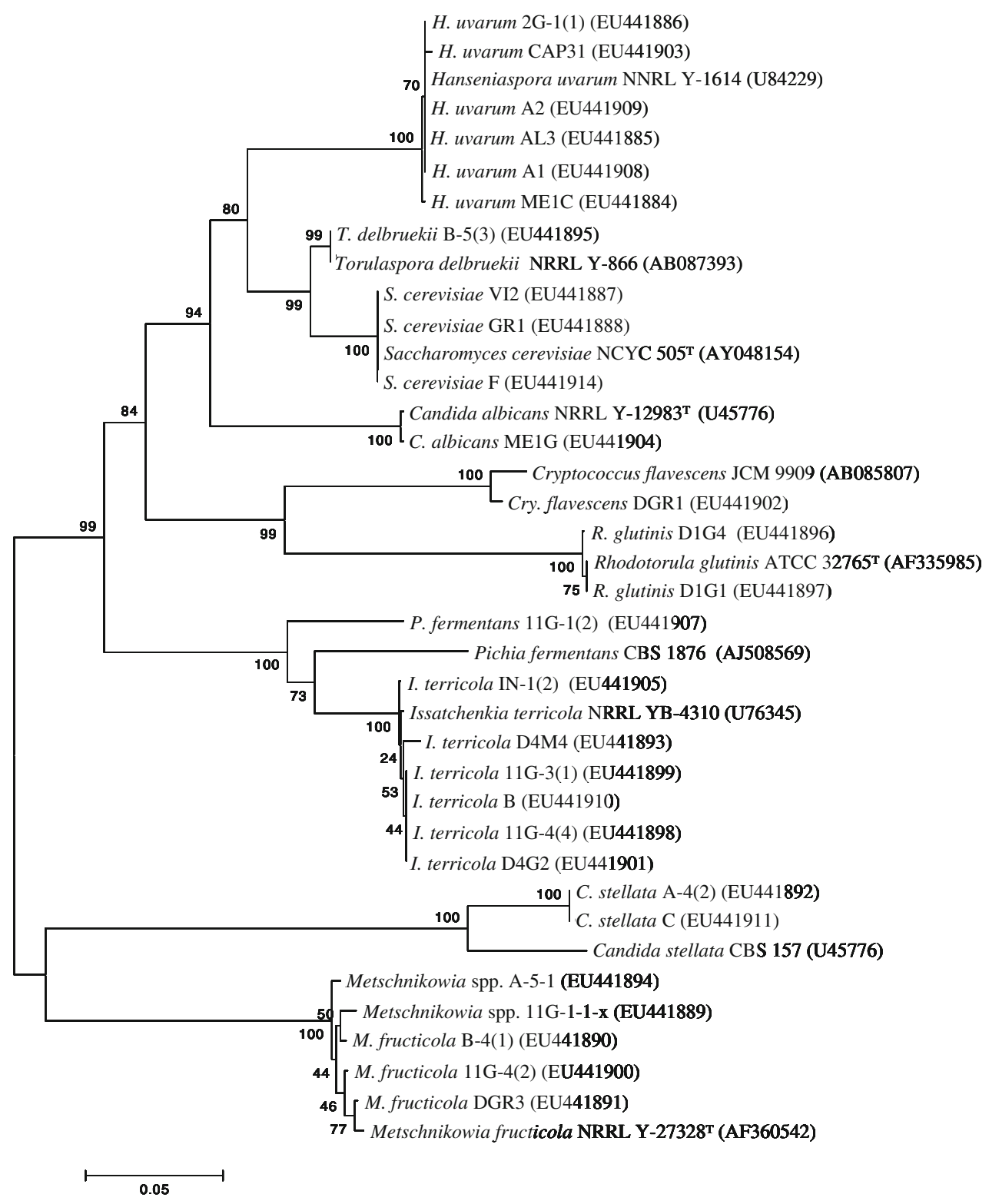

isolated from healthy grapes of Fontana Iuto vineyard, was chosen to be used as starter for a large-scale vinification.

In order to exclude clonal relatedness among strain GR1 and CDY, ten commercial yeasts usually employed in Taurasi cellars were analysed by RAPD-PCR. The pattern comparison excluded cross-contamination of CDY in the vineyard (data not shown).

Factory-scale vinification process

\section{Fate of fermenting yeasts}

Two vinifications were performed at large-scale level employing the indigenous $S$. cerevisiae GR1 and CDY and samples for analysis were collected during fermentation
(Table 2). Wild yeast concentration of must before starter addition (M1) was estimated at around $10^{6} \mathrm{CFU} / \mathrm{ml}$ on MEAC and $10^{2} \mathrm{CFU} / \mathrm{ml}$ on MESA medium (Fig. 3). The two media allowed a selective yeast growth, since MESA was able to count species considered to be relevant in fermentation. The clarification process produced a must (M2) where yeast population on MEAC medium drastically decreased. After starter addition (M3), yeast counts were almost $10^{7} \mathrm{CFU} / \mathrm{ml}$ for both vinifications, as estimated on MEAC, while lower levels were detected on MESA. At the fourth day of fermentation (F1), yeast concentrations were similar (ca. $5 \times 10^{7} \mathrm{CFU} / \mathrm{ml}$ ) for both processes on both media (Fig. 3). Cell counts remained comparable and slightly decreased till the 11th day (F3), when musts were transferred into the barriques. After the first 7 days 

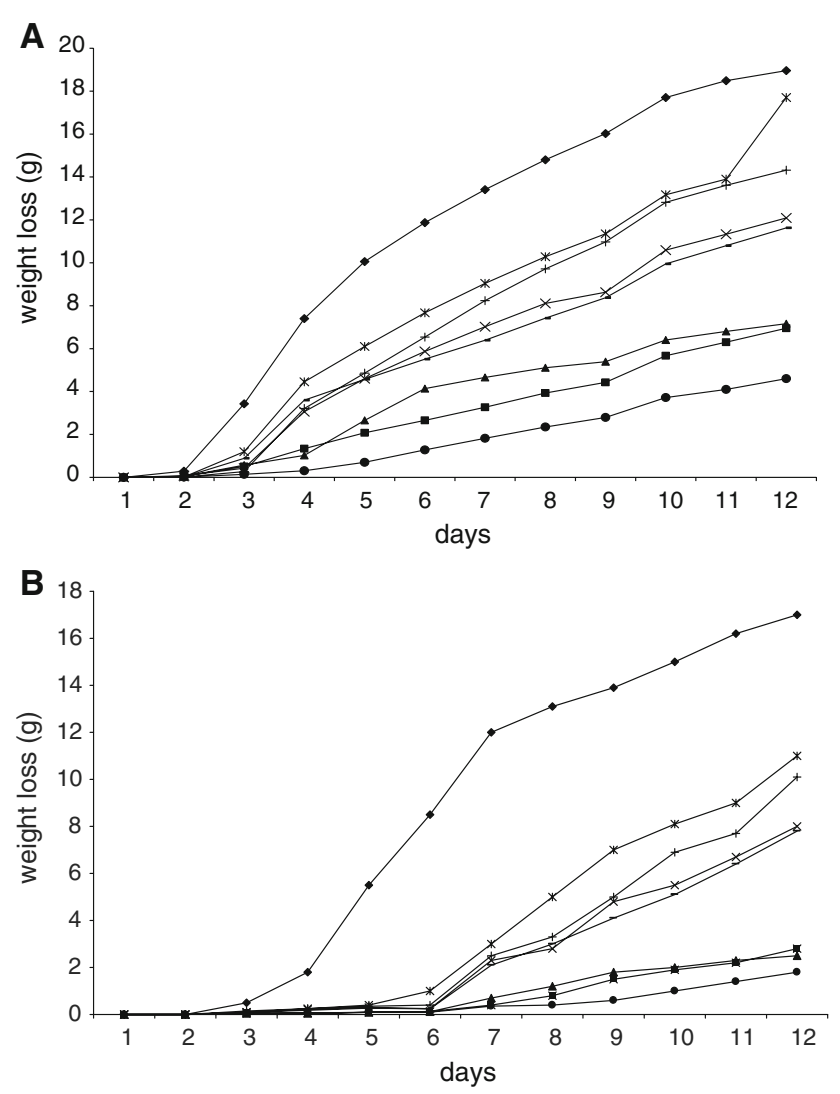

Fig. 2 Must weight loss of representative yeast strains during must fermentation at $18^{\circ} \mathrm{C}(\mathbf{a})$ and $10^{\circ} \mathrm{C}(\mathbf{b})$ in presence of $\mathrm{SO}_{2}$. Strains are as follows: GR1 (filled diamond), GR2 (times) and GR3 (dash), S. cerevisiae; A-4(2) (filled square), C. stellata; CAP31 (filled triangle), H. uvarum; B-5(3) (filled circle), T. delbrueckii; L2 (asterisk) and L3 (plus), commercial dry S. cerevisiae (positive controls). Results indicate mean value of two independent experiments

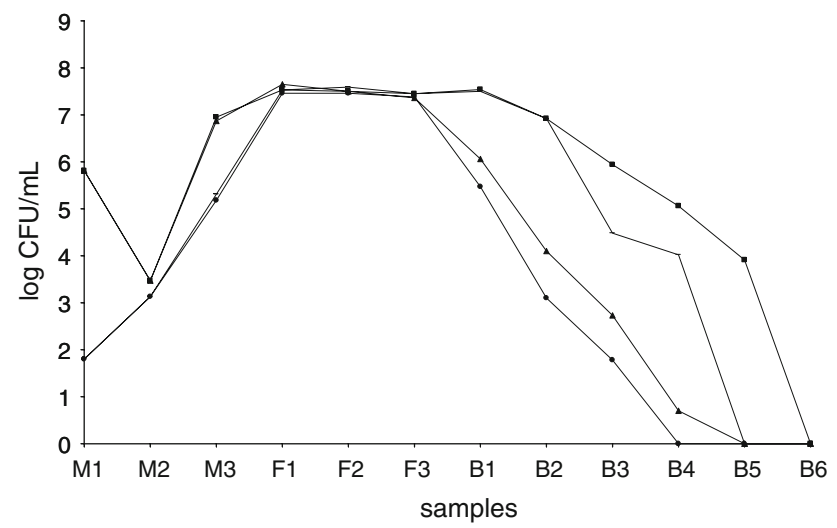

Fig. 3 Cell concentrations of CDY and GR1 large-scale vinifications: CDY vinification monitored by MEAC (filled triangle) and MESA (filled circle); GR1 vinification monitored by MEAC (filled square) and MESA (dash). Results indicate mean value of two independent experiments

post-fermentation (B1) CDY was around $10^{6} \mathrm{CFU} / \mathrm{ml}$ on MEAC and $10^{5} \mathrm{CFU} / \mathrm{ml}$ on MESA, while $S$. cerevisiae GR1 a little more than $10^{7} \mathrm{CFU} / \mathrm{ml}$. From the 15 th day of aging in barrique onward, yeast concentration decreased for both vinifications. CDY process showed a quicker lowering in cell counts than GR1 process. After 51 days in barrique, yeasts from control vinification, as well as those from GR1 vinification on MESA medium were not found, whereas yeasts from GR1 process were almost $10^{4} \mathrm{CFU} / \mathrm{ml}$ as counted on MEAC.

Thirty colonies at each sampling time were recovered from MEAC plates for GR1 vinification. The isolates were analysed by RAPD-PCR which generated seven clusters (Table 3) and the seven representative strains were identified by the partial 26S rRNA gene sequence analysis. $H$. uvarum dominated the non-inoculated must (M1), Issatchenkia terricola, Candida stellata, Pichia galeiformis and Zygosaccharomyces bailii were found after clarification, while $S$. cerevisiae was the only species isolated from the inoculation till the 51st day of permanence in barrique.

PCR-DGGE analysis performed with the primer pair 403-f/662-r generated a higher number of bands as compared to the NL1/NL2. In the first case, four bands corresponding to Hanseniaspora spp., C. stellata, Botryotinia fuckeliana and Aureobasidium pullulans were found both before and after must clarification (Fig. 4a), while only a band ascribable to Candida spp. was revealed with the primers 403-f and 662-r (Fig. 4b). S. cerevisiae was well detected as unique species by both primer pairs at the other sampling times.

\section{Chemical and sensory analysis}

Statistical analysis of data regarding conventional parameters commonly evaluated during a wine-making process showed significant $(P<0.05$ at least $)$ differences between vinifications carried out with GR1 and CDY (Table 4). However, some parameters such as $\mathrm{pH}$ measured at $\mathrm{F} 1$ and $\mathrm{F} 3,{ }^{\circ} \mathrm{Brix}$ at $\mathrm{F} 1$ and $\mathrm{B} 5$, alcohol content at Bw and $\mathrm{OD}$ at $\mathrm{Bw}$, were not found to be different for the two processes.

Twenty-nine VOC were identified in the aroma of fermented grape musts at least in one process. The $20 \mathrm{VOC}$ (Table 5) found in both vinifications were statistically analysed and the results obtained also led to the observation that strains GR1 and CDY determined differences during wine-makings starting form the same must. The only two VOC that were not found to be significant $(P>0.05)$ were methylvinylketon at B5 and butandioic acid methylbismethylpropylester at F3. Moreover, wine fermented with strain GR1 contained a higher VOC concentration than wine fermented with CDY. Alcohols represented the largest group of VOC detected during the whole wine production process followed by esters.

The two final wines were then judged by a panel of experienced wine-tasters. The majority of attributes examined were almost similar between the two wines (Fig. 5), 
Table 3 RAPD patterns detected and yeast species found during the large-scale fermentation process

\begin{tabular}{|c|c|c|c|c|c|c|c|c|c|c|}
\hline \multirow[t]{3}{*}{ RAPD pattern } & \multirow{2}{*}{\multicolumn{7}{|c|}{$\frac{\text { No. of isolates }}{\text { Fermentation time }}$}} & \multicolumn{3}{|c|}{ Molecular identification $^{\mathrm{a}}$} \\
\hline & & & & & & & & \multirow[t]{2}{*}{ Closest relative } & \multirow[t]{2}{*}{ Identity $\%$} & \multirow[t]{2}{*}{ GenBank accession no. } \\
\hline & M1 & M2 & M3 & $\mathrm{F} 1$ & $\mathrm{~F} 2$ & B1 & B5 & & & \\
\hline A1 & 27 & 0 & 0 & 0 & 0 & 0 & 0 & H. uvarum & 100 & EU441908 \\
\hline $\mathrm{A} 2$ & 3 & 0 & 0 & 0 & 0 & 0 & 0 & H. uvarum & 99 & EU441909 \\
\hline B & 0 & 21 & 0 & 0 & 0 & 0 & 0 & I. terricola & 99 & EU441910 \\
\hline $\mathrm{C}$ & 0 & 3 & 0 & 0 & 0 & 0 & 0 & C. stellata & 100 & EU441911 \\
\hline $\mathrm{D}$ & 0 & 3 & 0 & 0 & 0 & 0 & 0 & P. galeiformis & 99 & EU441912 \\
\hline $\mathrm{E}$ & 0 & 3 & 0 & 0 & 0 & 0 & 0 & Z. bailii & 99 & EU441913 \\
\hline $\mathrm{F}$ & 0 & 0 & 30 & 30 & 30 & 30 & 30 & S. cerevisiae & 99 & EU441914 \\
\hline
\end{tabular}

See Fig. 1 for the meaning of the abbreviations

$M 1$ just pressed must, $M 2$ clarified must, $M 3$ inoculated must, $F 14$ days fermentation, $F 28$ days fermentation, $B 17$ days barrique, $B 551$ days barriques

${ }^{a}$ As determined by partial $26 \mathrm{~S}$ rRNA gene sequencing

Fig. 4 DGGE analysis of PCR products amplified from GR1 large-scale fermentation at different sampling times. Lanes 1-7 correspond to the following samples: M1, M2, M3, F1, F2, F3 and B5 (see Table 2 for abbreviations). Species identities are as follows: Hsp, Hanseniaspora spp.; Cs, Candida stellata; Bf, Botryotinia fuckeliana; Ap, Aureobasidium pullulans; Sc, Saccharomyces cerevisiae; Csp, Candida spp.
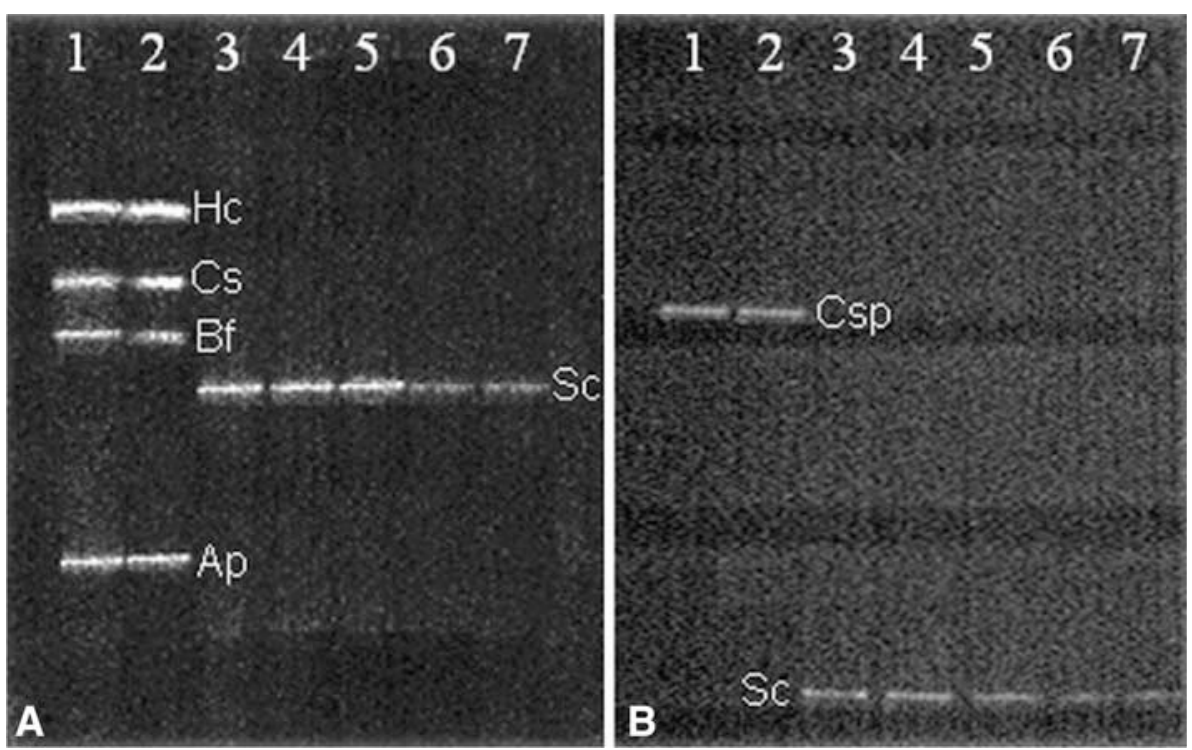

but the wine obtained after fermentation by GR1 strain was characterized by a higher smoked/roasted, fresh and mature fruit aromas as well as a higher hot sensation, "terroir" expression, intensity of smell, persistence of aromas and a general overall evaluation. However, with regards to CDY wine, panellists found in GR1 wine a lesser perception of vanilla/pepper and citrus fruit aromas, intensity of taste and balance.

\section{Discussion}

The knowledge of microorganisms living in a given environment may play a defining role in the process of understanding microbial interactions and technological aptitudes. The first main objective of the present study was the recovery and characterization of wild yeasts from several vineyard environments, in order to provide a more exhaustive view of yeast populations native of, hosted in, or vehiculated from various agents at the vineyards, as well as to screen for yeasts with potential in wine fermentation. The phylogenetic tree constructed on DNA fragments from the representative yeast strains showed a high correlation between RAPD and phylogenetic analysis; all strains with similar RAPD profiles were grouped together in the same species forming a distinct branch of the phylogenetic tree. C. stellata and C. albicans were not closely related, but this result is not surprising since several phylogenetic studies showed relevant distances among species in the Candida genus (Lu et al. 2004; Prasad et al. 2005; Robert et al. 2001). 
Table 4 Chemical composition of musts and wines obtained during the large-scale vinification process by GR1 and CDY

\begin{tabular}{|c|c|c|c|c|c|c|c|c|c|c|}
\hline \multirow{2}{*}{$\begin{array}{l}\text { Time: } \\
\text { Strain: }\end{array}$} & \multirow[t]{2}{*}{ M1 } & \multicolumn{5}{|l|}{$\mathrm{F} 1$} & \multicolumn{4}{|l|}{$\mathrm{F} 2$} \\
\hline & & \multicolumn{2}{|l|}{ GR1 } & \multicolumn{3}{|l|}{ CDY } & \multicolumn{2}{|l|}{ GR1 } & \multicolumn{2}{|c|}{$\mathrm{CDY}$} \\
\hline \multicolumn{11}{|l|}{ Parameters } \\
\hline $\mathrm{pH}$ & $3.43 \pm 0.01$ & \multicolumn{2}{|c|}{$3.26 \pm 0.01$} & \multicolumn{2}{|l|}{$3.27 \pm 0.01$} & nsd & \multicolumn{2}{|c|}{$3.18 \pm 0.01$} & $3.29 \pm 0.01$ & $\mathrm{sd}^{* *}$ \\
\hline${ }^{\circ}$ Brix & $20.6 \pm 0.12$ & \multicolumn{2}{|c|}{$15.00 \pm 0.20$} & \multicolumn{2}{|l|}{$14.83 \pm 0.06$} & nsd & \multicolumn{2}{|c|}{$12.03 \pm 0.06$} & $9.87 \pm 0.12$ & $\mathrm{sd}^{* *}$ \\
\hline TTA & $7.7 \pm 0.02$ & \multicolumn{2}{|c|}{$8.47 \pm 0.01$} & \multicolumn{2}{|c|}{$9.26 \pm 0.01$} & $\mathrm{sd}^{* *}$ & \multicolumn{2}{|c|}{$9.30 \pm 0.02$} & $8.52 \pm 0.02$ & $\mathrm{sd}^{* *}$ \\
\hline VA & $0.19 \pm 0.01$ & \multicolumn{2}{|c|}{$0.55 \pm 0.01$} & \multicolumn{2}{|c|}{$0.31 \pm 0.01$} & $\mathrm{sd}^{* *}$ & \multicolumn{2}{|c|}{$0.48 \pm 0.01$} & $0.39 \pm 0.01$ & $\mathrm{sd}^{* *}$ \\
\hline Alcohol (\% v/v) & nd & $4.77 \pm$ & 0.01 & $5.43 \pm 0.0$ & & $\mathrm{sd}^{* *}$ & 9.69 & \pm 0.02 & $10.54 \pm 0.02$ & $\mathrm{sd}^{* *}$ \\
\hline Dry extract $(\mathrm{g} / \mathrm{l})$ & $244 \pm 0.21$ & $156.17 \pm$ & 0.15 & $160.83 \pm 0.4$ & & $\mathrm{sd}^{* *}$ & 80.40 & \pm 0.10 & $94.71 \pm 0.01$ & $\mathrm{sd}^{* *}$ \\
\hline Reducing sugars $(\% \mathrm{w} / \mathrm{v})$ & $18.8 \pm 0.04$ & $14.49 \pm$ & 0.03 & $10.75 \pm 0.0$ & & $\mathrm{sd}^{* *}$ & 9.93 & \pm 0.03 & $2.46 \pm 0.03$ & $\mathrm{sd}^{* *}$ \\
\hline $\mathrm{TP}$ & $248 \pm 0.25$ & $246.00 \pm$ & 1.00 & $299.33 \pm 0.5$ & & $\mathrm{sd}^{* *}$ & 378.67 & \pm 0.58 & $312.90 \pm 0.17$ & $\mathrm{sd}^{* *}$ \\
\hline Tannins (ppm catechin) & $132 \pm 0.15$ & $88.30 \pm$ & 0.10 & $100.33 \pm 0.5$ & & $\mathrm{sd}^{* *}$ & 131.33 & \pm 0.58 & $117.93 \pm 0.12$ & $\mathrm{sd}^{* *}$ \\
\hline Turbidity (FTU) & $2113 \pm 1.53$ & $2059.33 \pm$ & 1.53 & $1820 \pm 1.0$ & & $\mathrm{sd}^{* *}$ & 822.00 & \pm 3.61 & $526.00 \pm 2.65$ & $\mathrm{sd}^{* *}$ \\
\hline $\mathrm{OD}(\mathrm{ABS})$ & $0.99 \pm 0.02$ & $0.95 \pm$ & 0.01 & $0.86 \pm 0.0$ & & $\mathrm{sd}^{*}$ & 0.91 & \pm 0.03 & $0.77 \pm 0.02$ & $\mathrm{sd}^{*}$ \\
\hline Total $\mathrm{SO}_{2}(\mathrm{mg} / \mathrm{l})$ & $87.6 \pm 0.06$ & $83.78 \pm$ & 0.02 & $80.17 \pm 0.1$ & & $\mathrm{sd}^{* *}$ & 70.97 & \pm 0.35 & $88.33 \pm 0.01$ & $\mathrm{sd}^{* *}$ \\
\hline Free $\mathrm{SO}_{2}(\mathrm{mg} / \mathrm{l})$ & $5.85 \pm 0.02$ & $5.76 \pm$ & 0.02 & $7.04 \pm 0.0$ & & $\mathrm{sd}^{* *}$ & 5.76 & \pm 0.02 & $7.67 \pm 0.03$ & $\mathrm{sd}^{* *}$ \\
\hline Combined $\mathrm{SO}_{2}(\mathrm{mg} / \mathrm{l})$ & $81.7 \pm 0.06$ & $70.15 \pm$ & 0.05 & $73.07 \pm 0.0$ & & $\mathrm{sd}^{* *}$ & 65.20 & \pm 0.10 & $80.64 \pm 0.02$ & $\mathrm{sd}^{* *}$ \\
\hline Acetaldehyde (mg/l) & $0.93 \pm 0.08$ & $13.20 \pm$ & 0.10 & $15.19 \pm 0.2$ & & $\mathrm{sd}^{* *}$ & 12.07 & \pm 0.06 & $18.02 \pm 0.08$ & $\mathrm{sd}^{* *}$ \\
\hline Time: & $\mathrm{F} 3$ & & & B5 & & & & $\mathrm{BW}$ & & \\
\hline Strain: & GR1 & $\mathrm{CDY}$ & & GR1 & $\mathrm{CD}$ & & & GR1 & $\mathrm{CDY}$ & \\
\hline Parameters & & & & & & & & & & \\
\hline $\mathrm{pH}$ & $3.32 \pm 0.01$ & $3.33 \pm 0.00$ & nsd & $3.28 \pm 0.01$ & & $5 \pm 0.01$ & $\mathrm{sd}^{*}$ & $3.44 \pm 0.01$ & $3.55 \pm 0.01$ & $\mathrm{sd}^{* *}$ \\
\hline${ }^{\circ}$ Brix & $8.00 \pm 0.10$ & $7.00 \pm 0.10$ & $\mathrm{sd}^{* *}$ & $6.77 \pm 0.06$ & & $7 \pm 0.06$ & nsd & $6.97 \pm 0.06$ & $6.83 \pm 0.01$ & $\mathrm{sd}^{*}$ \\
\hline TTA & $9.78 \pm 0.01$ & $8.90 \pm 0.02$ & $\mathrm{sd}^{* *}$ & $7.12 \pm 0.01$ & & $3 \pm 0.06$ & $\mathrm{sd}^{* *}$ & $8.36 \pm 0.02$ & $7.42 \pm 0.03$ & $\mathrm{sd}^{* *}$ \\
\hline VA & $0.38 \pm 0.01$ & $0.36 \pm 0.01$ & $\mathrm{sd}^{*}$ & $0.36 \pm 0.01$ & & $5 \pm 0.01$ & $\mathrm{sd}^{* *}$ & $0.57 \pm 0.01$ & $0.60 \pm 0.01$ & $\mathrm{sd}^{*}$ \\
\hline Alcohol (\% v/v) & $13.13 \pm 0.12$ & $13.45 \pm 0.01$ & $\mathrm{sd}^{*}$ & $13.73 \pm 0.03$ & & $.43 \pm 0.03$ & $\mathrm{sd}^{* *}$ & $13.27 \pm 0.11$ & $13.66 \pm 0.02$ & nsd \\
\hline Dry extract $(\mathrm{g} / \mathrm{l})$ & $62.17 \pm 0.12$ & $74.28 \pm 0.03$ & $\mathrm{sd}^{* *}$ & $23.19 \pm 0.01$ & & $.45 \pm 0.05$ & $\mathrm{sd}^{* *}$ & $20.57 \pm 0.06$ & $17.86 \pm 0.01$ & $\mathrm{sd}^{* *}$ \\
\hline Reducing sugars $(\% \mathrm{w} / \mathrm{v})$ & nd & nd & & nd & nd & & & nd & nd & \\
\hline $\mathrm{TP}$ & $314.23 \pm 0.25$ & $331.30 \pm 0.26$ & $\mathrm{sd}^{* *}$ & $171.00 \pm 1.00$ & & $8.87 \pm 0.32$ & $\mathrm{sd}^{* *}$ & $240.67 \pm 0.58$ & $8297.33 \pm 0.21$ & $\mathrm{sd}^{* *}$ \\
\hline Tannins (ppm catechin) & $126.87 \pm 0.81$ & $101.43 \pm 0.45$ & $\mathrm{sd}^{* *}$ & $72.03 \pm 0.35$ & & $63 \pm 0.15$ & $\mathrm{sd}^{* *}$ & $85.47 \pm 0.23$ & $90.27 \pm 0.31$ & $\mathrm{sd}^{* *}$ \\
\hline Turbidity (FTU) & $394.33 \pm 1.53$ & $1232.00 \pm 4.00$ & $\mathrm{sd}^{* *}$ & $19.57 \pm 0.25$ & & $4 \pm 0.04$ & $\mathrm{sd}^{* *}$ & $4.06 \pm 0.02$ & $2.13 \pm 0.02$ & $\mathrm{sd}^{* *}$ \\
\hline $\mathrm{OD}(\mathrm{ABS})$ & $0.85 \pm 0.01$ & $0.75 \pm 0.01$ & $\mathrm{sd}^{* *}$ & $0.14 \pm 0.01$ & & $1 \pm 0.00$ & $\mathrm{sd}^{*}$ & $0.11 \pm 0.01$ & $0.12 \pm 0.02$ & nsd \\
\hline Total $\mathrm{SO}_{2}(\mathrm{mg} / \mathrm{l})$ & $35.73 \pm 0.12$ & $24.34 \pm 0.02$ & $\mathrm{sd}^{* *}$ & $55.23 \pm 0.25$ & & $10 \pm 0.26$ & $\mathrm{sd}^{* *}$ & $80.10 \pm 0.10$ & $58.88 \pm 0.04$ & $\mathrm{sd}^{* *}$ \\
\hline Free $\mathrm{SO}_{2}(\mathrm{mg} / \mathrm{l})$ & $5.75 \pm 0.01$ & $3.83 \pm 0.01$ & $\mathrm{sd}^{* *}$ & $7.07 \pm 0.03$ & & $4 \pm 0.06$ & $\mathrm{sd}^{* *}$ & $4.47 \pm 0.04$ & $5.15 \pm 0.02$ & $\mathrm{sd}^{* *}$ \\
\hline Combined $\mathrm{SO}_{2}(\mathrm{mg} / \mathrm{l})$ & $30.14 \pm 0.05$ & $20.48 \pm 0.04$ & $\mathrm{sd}^{* *}$ & $48.05 \pm 0.13$ & & $.70 \pm 0.30$ & $\mathrm{sd}^{* *}$ & $75.40 \pm 0.26$ & $53.77 \pm 0.04$ & $\mathrm{sd}^{* *}$ \\
\hline Acetaldehyde (mg/l) & $18.27 \pm 0.15$ & $23.06 \pm 0.06$ & $\mathrm{sd}^{* *}$ & $14.43 \pm 0.21$ & & $13 \pm 0.15$ & $\mathrm{sd}^{* *}$ & $16.58 \pm 0.07$ & $13.19 \pm 0.09$ & $\mathrm{sd}^{* *}$ \\
\hline
\end{tabular}

$T T A$ total titratable acidity (g/l tartaric acid), $V A$ volatile acidity (g/l acetic acid), $T P$ total polyphenols (ppm gallic acid), $O D$ optical density, $n d$ not detected (value $<$ detection limit of method), $n s d$ not statistically different

sd $^{*}$ statistically different $(P<0.05)$; sd ${ }^{* *}$ statistically different $(P<0.001)$

As expected, yeast concentrations from grape materials (bunches and musts) were between 2 and 4 order of magnitude higher than those from the other vineyard matrices (barks, leaves, grass and soil). Yeast counts from birds and insects could not be performed in terms of cell concentration. With regards to the grape samples, in agreement with Prakitchaiwattana et al. (2004), we found higher yeast numbers on the skin of damaged grapes than healthy fruits.
H. uvarum and Metschnikowia spp. were the most common species isolated in the four vineyards studied, as being part of a stable community of Taurasi area at the time of vintage of the present experimentation. Other yeast species were merely found in one or two vineyards, contributing, however, in increasing the variability within the sampling sites. Our results showed qualitative and quantitative differences in yeast composition from vineyards far less than $1 \mathrm{~km}$ 


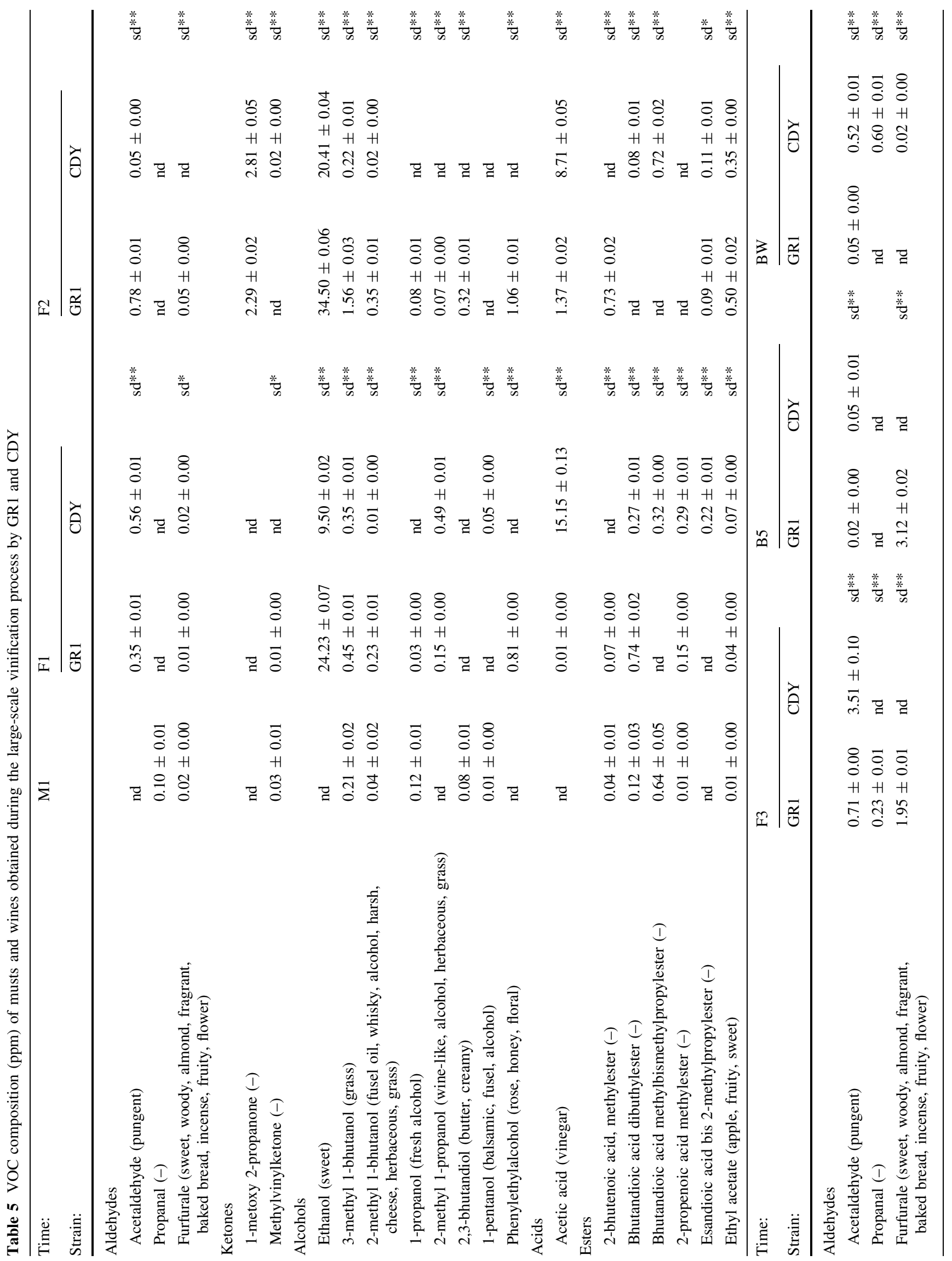




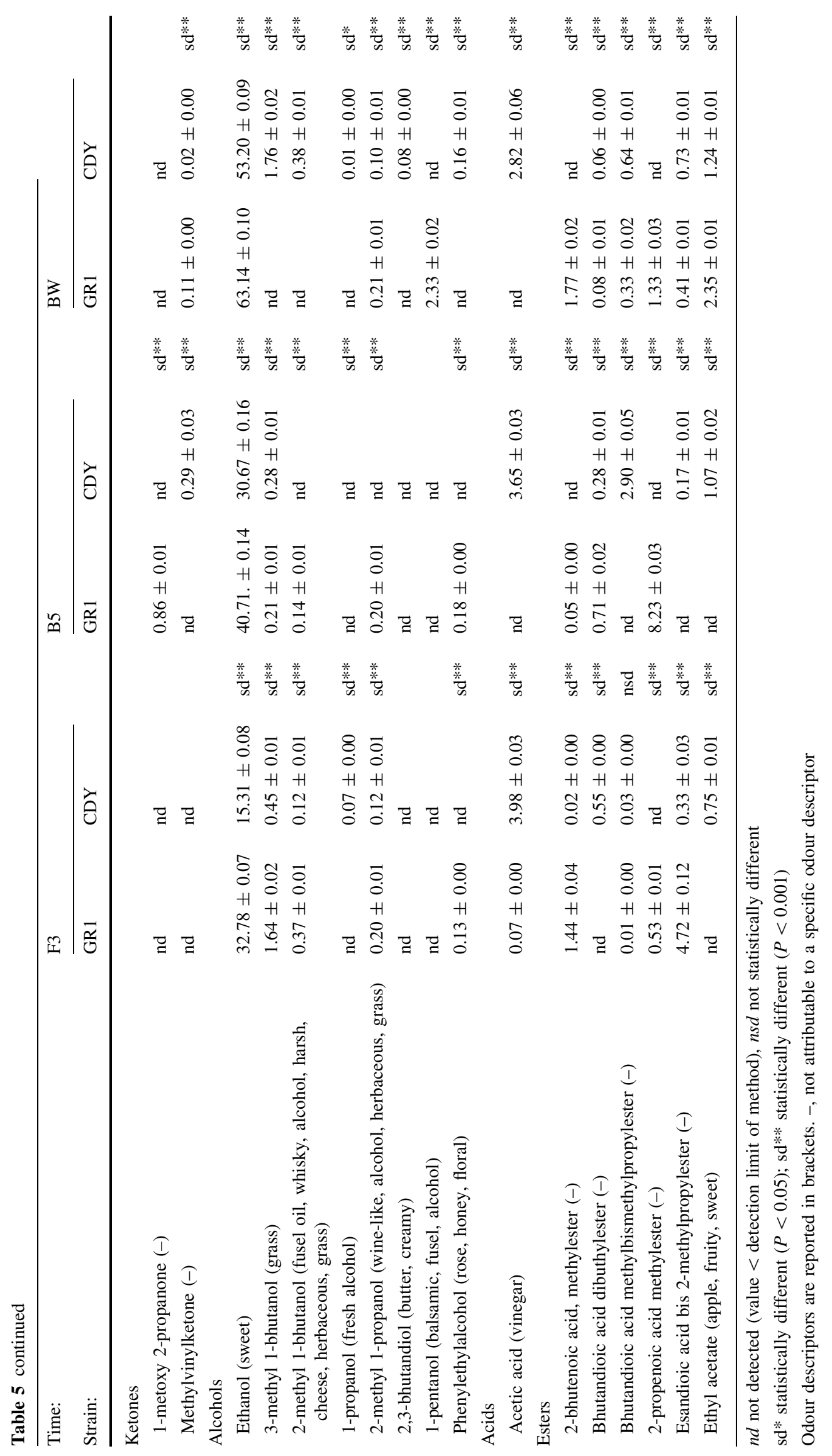




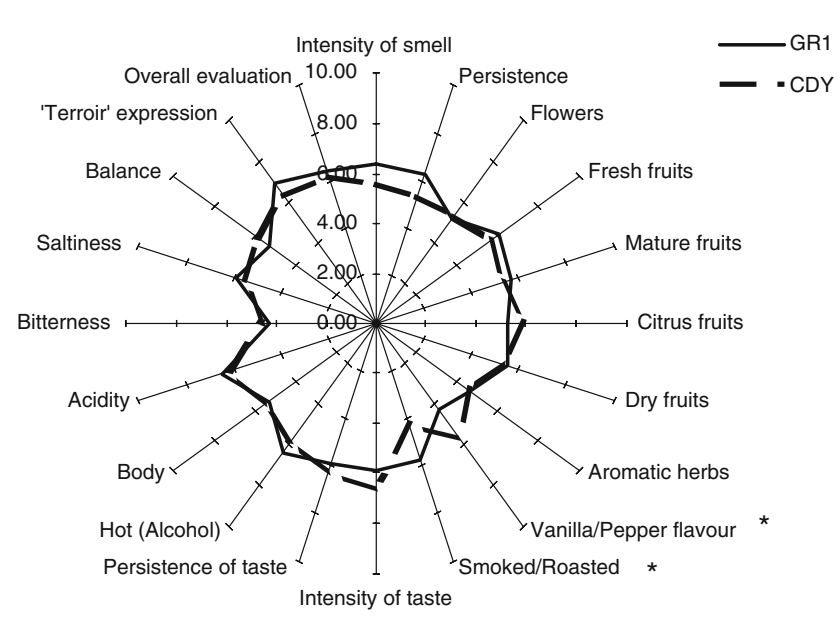

Fig. 5 Sensory analysis of the wines inoculated with GR1 and CDY. Asterisks indicate descriptors statistically different $(P<0.05)$ between the two wines

from one another, thus confirming the observation that geographical location and microclimatological changes may influence species diversity (Raspor et al. 2006) and support the idea of 'terroir' on the expression of wines, also at the microbial-level (Renouf et al. 2006).

Yeast species with no role in fermentation, such as Rhodotorula glutinis and I. terricola disappeared from musts. On the contrary, once in musts, H. uvarum strains increased their cell concentration; this species, together with Metschnikowia spp., is known to dominate the yeast population during the early stages of wine fermentations (Heard and Fleet 1985; Rosini et al. 1982).

To our knowledge, this research showed a new finding regarding the ecology of vineyards and represents the first report on fermenting yeasts carried by birds. Yeasts belonging to species with potential in wine fermentation were isolated from the mouth and cloacae of vineyard inhabiting (sedentary) birds, while no yeasts with this characteristic were found in migratory birds. Vineyard inhabiting birds were partly responsible for dissemination of fermentative yeasts during their feeding activities. So far, several studies have been conducted on yeasts isolated from different part of the body and/or feaces of birds, but only for medical implications (Mancianti et al. 2001; Ramirez et al. 1976; Refai et al. 1983).

According to a statement of Loureiro and MalfeitoFerreira (2007), S. cerevisiae strains are brought to the berries by insects and birds. However, the results obtained showed that no wine relevant yeasts were vehiculated by migrating birds, thus the relationships between yeast species and birds could not be durable, while temporary associations related to the feeding habits might be assumed.

The origin of $S$. cerevisiae strains is quite hard to retrieve. Some researchers stated that $S$. cerevisiae, even at extremely low cell numbers (Mortimer and Polsinelli 1999;
Torok et al. 1996), are present in the vineyard environment, while others claimed that a natural origin for $S$. cerevisiae should be excluded, pointing to a direct association with artificial, man-made environments, such as wineries and fermentation plants (Martini 1993). The finding of a strain of $S$. cerevisiae from healthy grapes would confirm the vineyard origin for this species.

This study was also directed to evaluate whether the utilization of an indigenous starter culture could bring to better oenological results than a CDY selected in a different vineyard area. With this in mind, the wine-making process (from must inoculation till bottling) was followed for a $S$. cerevisiae strain selected in this study and a commercial starter yeast routinely used in the cellar where fermentations were carried out. The indigenous strain used (GR1) was chosen among strains isolated from Taurasi area, which showed the best behaviour both at 18 and $10^{\circ} \mathrm{C}$ (Fig. 2). H. uvarum was the only species detected in the must before the 'debourbage' (MBSK and PVPP addition), a common clarification step in white wine-making. The dominance of non-Saccharomyces species at the beginning of the fermentation processes is a well known phenomenon. However, after the action of PVPP and MBSK, the latter has a selective effect on yeast microbiota, yeasts were strongly reduced in number and $H$. uvarum was no more recognized by RAPD-PCR, while C. stellata and Z. bailii were clearly identified. This observation maybe explained by the fact that species of genera Candida and Zygosaccharomyces are notoriously resistant to a concentration 10-fold higher than that inhibiting H. uvarum (Romano and Suzzi 1993; Warth 1985).

PCR-DGGE is a powerful method for assessing the structure of microbial communities in environmental samples (Muyzer and Smalla 1998). In complex matrices like wines, the detection limit of DGGE technique has been reported to be around $10^{3} \mathrm{CFU} / \mathrm{ml}$ (Cocolin et al. 2000). Two couples of primers were used to reveal yeast diversity during the experimental fermentations carried out in the present study, which showed a different detection sensibility. Besides C. stellata and Hanseniaspora spp., PCR-DGGE showed the presence of B. fuckeliana and A. pullulans in the must, species that could not be identified by the culture-dependent methods. On the other hand, the last tools were able to identify I. terricola, $P$. galeiformis and Z. bailii, thus highlighting the high power of a combined culture-dependent and -independent approach to describe the microbiota of a certain environment in a more complete manner. Since B. fuckeliana is a grapevine pathogen (Grey rot) and A. pullulans showed a marked antagonistic effect on yeasts and fungi (Castoria et al. 2001), their detection maybe of paramount importance.

After starter inoculation, culture-dependent and -independent approaches agreed in showing the prevalence and 
persistence of GR1 and CDY. However, CDY showed a limited persistence (33 days) compared to GR1 which lasted until the 51st day.

During fermentation, yeasts produced a wide variety of secondary products (alcohols, esters, acids, aldehydes, ketones, lactones, terpenoids and phenols) that contribute significantly, especially higher alcohols and esters (Ferreira et al. 1995), to the sensory properties of wines. The differences between fermentation by GR1 and CDY were first in terms of VOC concentration. GR1 vinification presented higher concentration of alcohols and esters than CDY vinification. Some of these compounds have a sensory relevance for their fruity and herbal aromas (Ebeler 2001; Rapp 1998). Sensory analysis of the wines obtained using the two starters revealed that perceived attributes were appreciably different, thus confirming chemical observation. The results of this work suggested that vineyard exerts a strong influence on the shaping of yeast communities and consequently on the characteristics of the final wines.

Acknowledgements We thank Alessandro Lonardo, owner of "Azienda Agricola Contrade di Taurasi" (Taurasi, AV, Italy) and Angela Balsamo, Ciro Sannino, Giuseppe Meca, Nicola Di Salvatore for their technical assistance. We would like to thank Antonella Monaco for information about 'Greco Muscio' grapevine variety, Maurizio De Simone for his oenological help in the cellar and Sergio Scebba for his collaboration in ringing birds. A special thank to Rodrigo Costa for the critical reading of this manuscript.

\section{References}

AOAC (1984) Official methods of analysis. Association of Official Analytical Chemists, Washington, DC

Castoria R, De Curtis F, Lima G, Caputo S, Pacifico S, De Cicco V (2001) Aureobasidium pullulans (LS-30) an antagonist of postharvest pathogens of fruits: study on its modes of action. Postharvest Biol Technol 22:7-17

Cocolin L, Bisson LF, Mills DA (2000) Direct profiling of yeast dynamics in wine fermentations. FEMS Microbiol Lett 189: $81-87$

Cocolin L, Heisey A, Mills DA (2001) Direct identification of the indigenous yeasts in commercial wine fermentations. Am J Enol Vitic 52:49-53

Ebeler SE (2001) Analytical chemistry: unlocking the secrets of wine flavor. Food Rev Int 17:45-64

Esteve-Zarzoso B, Gostincar A, Bobet R, Uruburu F, Querol A (2000) Selection and molecular characterization of wine yeasts isolated from "El Penedes" area (Spain). Food Microbiol 17:553-562

Farris GA, Budroni M, Vodret T, Deiana P (1990) Sull'origine dei lieviti vinari i lieviti dei terreni, della foglie e degli acini di alcuni vigneti sardi. L'Enotecnico 6:99-108

Ferreira V, Fernandez P, Pena C, Escudero A, Cacho JF (1995) Investigation on the role played by fermentation esters in the aroma of young Spanish wines by multivariate analysis. J Sci Food Agric 6:381-392

Fleet GH (1990) Growth of yeasts during wine fermentations. J Wine Res 1:211-223

Fleet GH (2003) Yeast interaction and wine flavours. Int J Food Microbiol 86:11-12
Francesca N, Monaco A, Romano R, Lonardo E, De Simone M, Moschetti G (2009) Rovello bianco, caratterizzazione di un vitigno autoctono campano. Vignevini 4:106-111

Froio G (1875) Primi Studi ampelografici del Principato Citeriore e del Principato Ulteriore. In: Ministero Agricoltura, Industria e Commercio (ed) Bollettino Ampelografico III. Ministero Agricoltura, Industria e Commercio, Roma, pp 20-46

González SS, Barrio E, Querol A (2006) Molecular identification and characterization of wine yeasts isolated from Tenerife (Canary Island, Spain). J Appl Microbiol 102:1018-1025

Heard GM, Fleet GH (1985) Growth of natural yeast flora during the fermentation of inoculated wines. Appl Environ Microbiol 50:727-728

Huerta Diaz-Reganon MD (1996) Evaluacion de Parametros para la Diferenciacion de Vinos de la Comunidad Autonoma de Madrid. $\mathrm{PhD}$ Thesis, University de Alcala de Henares, Madrid

Hunter PR, Gaston MA (1988) Numerical index of the discriminatory ability of typing systems: an application of Simpson's index of diversity. J Clin Microbiol 26:2465-2466

Kish AD, Sharf R, Margalith P (1983) A note on a selective medium for wine yeasts. J Appl Bacteriol 55:177-179

Kumar S, Tamura K, Nei M (2004) MEGA3: integrated software for molecular evolutionary genetics analysis and sequence alignment. Brief Bioinform 5:150-163

Longo E, Cansado J, Agrelo D, Villa TG (1991) Effect of climatic conditions on yeast diversity in grape musts from Northwest Spain. Am J Enol Vitic 42:141-144

Lopandic K, Tiefenbrunner W, Gangl H, Mandl K, Berger S, Leitner G, Abd-Ellah GA, Querol A, Gardner RC, Sterflinger K, Prillinger H (2008) Molecular profiling of yeasts isolated during spontaneous fermentations of Austrian wines. FEMS Yeast Res 8:1063-1075

Loureiro V, Malfeito-Ferreira M (2007) The ecology of contamination yeasts on wine grapes. In: Proceedings of the international specialized symposium on yeasts ISSY26, Sorrento, Italy, p 47

Lu H-Z, Jia J-H, Wang Q-M, Bai F-Y (2004) Candida asparagi sp. nov., Candida diospyri sp. nov. and Candida qinlingensis sp. nov., novel anamorphic, ascomycetous yeast species. Int J Syst Evol Microbiol 54:1409-1414

Mancianti F, Tardoni S, Cecherelli R (2001) Occurrence of yeasts in psittacines droppings from captive birds in Italy. Mycopathologia 153:121-124

Martinez J, Millan C, Ortega JM (1989) Growth of natural flora during fermentation of inoculated musts from Pedro Ximenez grapes. South Afr J Enol Vitic 10:31-35

Martini A (1993) The origin and domestication of the wine yeast Saccharomyces cerevisiae. J Wine Res 4:165-176

Martini A, Federichi F, Rosini G (1980) A new approach to the study of yeast ecology of natural substrates. Can J Microbiol 26: 856-859

Moreno JJ, Millan C, Ortega JM, Medina M (1991) Analytical differentiation of wine fermentations using pure and mixed yeast cultures. J Ind Microbiol 7:181-190

Mortimer RK, Polsinelli M (1999) On the origin of wine yeast. Res Microbiol 150:199-204

Mortimer RK, Romano P, Suzzi G, Polsinelli M (1994) Genome renewal: a new phenomenon revealed from a genetic study of 43 strains of Saccharomyces cerevisiae derived from natural fermentation of grape musts. Yeast 10:1543-1552

Moschetti G, Blaiotta G, Aponte M, Catzeddu P, Villani F, Deiana P, Coppola S (1998) Random amplified polymorphic DNA and amplified ribosomal DNA spacer polymorphism: powerful methods to differentiate Streptococcus thermophilus strain. J Appl Microbiol 85:25-36

Muyzer G, Smalla K (1998) Application of DGGE and TGGE in microbial ecology. Antonie van Leeuwenhoek 73:127-141 
O’Donnell K (1993) Fusarium and its near relatives. In: Reynolds DR, Taylor JW (eds) The fungal anamorph: mitotic, meiotic and pleomorphic speciation in fungal systematics. CAB International, Wallingford, pp 225-233

O.I.V. (1990) Compendium of international methods of wine and must analysis. International Organisation of Vine and Wine (OIV), Paris

Orlic S, Redzepovic S, Jeromel A, Herjavec S, Iacumin L (2007) Influence of indigenous Saccharomyces paradoxus strains on Chardonnay wine fermentation aroma. Int J Food Sci Technol 42:95-101

Parrish ME, Carrol DE (1985) Indigenous yeasts associated with muscadine (Vitis rotundifolia) grapes and must. Am J Enol Vitic 36:165-169

Prakitchaiwattana CJ, Fleet GH, Heard GM (2004) Application and evaluation of denaturing gradient gel electrophoresis to analyse the yeast ecology of wine grapes. FEMS Yeast Res 4:856-877

Prasad GS, Mayilarj S, Sood N, Singh V, Biswas K, Lal B (2005) Candida digboiensis sp. nov., a novel anamorphic yeast species from an acidic tar sludge-contaminated oilfield. Int J Syst Evol Microbiol 55:967-972

Pretorius IS (2000) Tailoring wine yeast for the new millennium: novel approaches to the ancient art of winemaking. Yeast 16:675-729

Pretorius IS, Van der Westhuizen TJ, Augustyn OPH (1999) Yeast biodiversity in vineyards and wineries and its importance to the South African wine industries. South Afr J Enol Vitic 20:61-74

Ramirez R, Robertstad GW, Hutchison LR, Chavez J (1976) Mycotic flora in the lower digestive tract of feral pigeons (Columba livia) in El Paso, Texas area. J Wildl Dis 12:83-85

Rapp A (1998) Volatile flavour of wine: correlation between instrumental analysis and sensory perception. Nahrung 42: $351-363$
Raspor P, Milek DM, Polanc J, Možina SS, Čadež N (2006) Yeasts isolated from three varieties of grapes cultivated in different locations of the Dolenjska vine-growing region, Slovenia. Int J Food Microbiol 109:97-102

Refai M, Taha M, Selim SA, Elshabourii F, Yusseff HH (1983) Isolation of Cryptococcus neoformans, Candida albicans and other yeasts from pigeon droppings in Egypt. Sabouraudia 21:163-165

Renouf V, Miot-Sertier C, Strehaiano P, Lonvaud-Funel A (2006) The wine microbial consortium: a real terroir characteristic. J Int des Sci de la Vigne et du Vin 40:209-216

Robert V, Bonjean B, Karutz M, Paschold H, Peeters W, Wubbolts MG (2001) Candida bituminiphila, a novel anamorphic species of yeast. Int J Syst Evol Microbiol 51:2171-2176

Romano P, Suzzi G (1993) Acetoin production in Saccharomyces cerevisiae wine yeasts. FEMS Microbiol Lett 108:23-26

Rosini G, Federichi F, Martini A (1982) Yeast flora of grape berries during ripening. Microb Ecol 8:83-89

Scebba S, Moschetti G (1996) Migration pattern and weight changes of Wood Sandpiper Tringa glareola in a stopover site in southern Italy. Ring Migr 17:101-104

Sigler WV, Turco RF (2002) The impact of chlorothalonil application on soil bacterial and fungal population as assessed by denaturing gradient gel electrophoresis. Appl Soil Ecol 21:107-118

Thompson JD, Gibson TJ, Plewniak F, Jeanmougin F, Higgins DG (1997) The CLUSTAL-X windows interface: flexible strategies for multiple sequence alignment aided by quality analysis tools. Nucleic Acids Res 25:4876-4882

Torok T, Mortimer RK, Romano P, Suzzi G, Polsinelli M (1996) Quest for wine yeasts - an old story revisited. J Ind Microbiol 17:303-313

Warth A (1985) Resistance of yeast species of benzoic and sorbic acids and to sulphur dioxide. J Food Prot 48:564-569 